\title{
Safety Attitudes Questionnaire - Intensive Care Unit Version: adaptation and validation for the Portuguese population
}

Questionário de Atitudes de Segurança - Versão Cuidados Intensivos: adaptação e validação para a população portuguesa

Cuestionario de Actitudes de Seguridad - Versión Cuidados Intensivos: adaptación y validación para la población portuguesa

Ricardo Águas*; Clara de Assis Coelho de Araújo**; Salete Soares ${ }^{* * *}$

\begin{abstract}
Background: Patient safety is a growing concern in the effort to achieve high levels of quality, not only for managers but also for health professionals and citizens.

Objective: To translate, adapt, and validate the Safety Attitudes Questionnaire - Intensive Care Unit version (SAQICU) for the Portuguese population.

Methodology: A methodological quantitative, observational, and cross-sectional study was conducted. The instrument was validated in a sample of 120 nurses working in intensive care units (ICUs).

Results: Nurses have a positive perception of patient safety, although they recognize the need to improve specific areas.

Conclusion: The Portuguese version of the SAQ-ICU showed good psychometric properties and proved to be a valid and reliable tool for the Portuguese population.
\end{abstract}

Keywords: patient safety; intensive care units; nursing; organizational culture

\section{Resumo}

Enquadramento: A segurança do doente assume uma preocupação crescente, não sendo somente uma preocupação dos gestores, mas mobilizando todos os profissionais de saúde e o cidadão para que sejam atingidos elevados níveis de qualidade.

Objetivo: Traduzir, adaptar e validar o Safety Attitudes Questionnaire - Intensive Care Version (SQA - ICU) para a população portuguesa.

Metodologia: Trata-se de um estudo de caráter metodológico, de abordagem quantitativa, observacional e transversal. A validação do instrumento foi realizada com uma amostra de 120 enfermeiros a desempenhar funçóes em unidades de cuidados intensivos (UCIs).

Resultados: Os enfermeiros apresentam positiva percepçáo sobre a segurança do doente, embora reconheçam necessidade de serem trabalhadas algumas áreas específicas.

Conclusão: O Questionário de Atitudes de Segurança - versão cuidados intensivos (QAS - UCI) versão portuguesa demonstrou possuir boas propriedades psicométricas, sendo válido e fiável para a população portuguesa.

Palavras-chave: segurança do paciente; unidades de terapia intensiva; enfermagem; cultura organizacional

*MSc., RN, Papworth Hospital, Cambridge, CB23 3RE, United Kindgom [Ricardoaguasm@gmail. $\mathrm{com}$. Contribution to the article: literature search, data collection, statistical treatment and evaluation, data analysis, and article writing. Address for correspondence: Alameda do Conde de Samodães, 157, 4430-999, Vila Nova de Gaia, Portugal.

**Ph.D., Coordinating Professor, School of Health, Polvtechnic Institute of Viana do Castelo, 4900347, Viana do Castelo, Portugal [claraaraujo@ess.ipvc.pt]. Contribution to the article: Guidance

and revision in article writing.
$* * *$ Ph.D., Adjunct Professor, School of Health, Polytechnic Institute of Viana do Castelo, 4900-347, revision in article writing
rang

\section{Resumen}

Marco contextual: La seguridad del paciente supone una preocupación cada vez mayor, y no se trata de un tema que preocupa solo a los gestores, sino que afecta a todos los profesionales de la salud y al ciudadano para conseguir un nivel alto de calidad.

Objetivo: Traducir, adaptar y validar el Safety Attitudes Questionnaire - Intensive Care Version (SQA - ICU) para la población portuguesa.

Metodología: Se trata de un estudio de carácter metodológico, de enfoque cuantitativo, observacional y transversal. La validación del instrumento se realizó con una muestra de 120 enfermeros que desempeñaban sus funciones en unidades de cuidados intensivos (UCIs).

Resultados: Los enfermeros presentan una percepción positiva sobre la seguridad del paciente, aunque reconocen que es necesario trabajar algunas áreas específicas.

Conclusión: El Cuestionario de Actitudes de Seguridad - versión cuidados intensivos (QAS - UCIs) versión portuguesa demostró que posee buenas propiedades psicométricas, y que es válido y fiable para la población portuguesa.

Palabras clave: seguridad del paciente; unidades de cuidados intensivos; enfermería; cultura organizacional 


\section{Introduction}

Over the years, patient safety and error reduction have been a growing concern for those involved in health practices. Errors represent a cost that is reflected in the lack of user trust in healthcare systems. As part of a highly complex care network with significant challenges, all parties involved - society, individuals, health professionals, governments, and associations - must focus their attention on patient safety. Health care providers must comply with quality requirements that significantly raise the standards to such levels that the complexity of tasks, the environment where they are performed, and the conditions in which they occur may be seen as the main variables influencing the occurrence of errors (Fragata, 2011).

Intensive care units (ICUs) are highly complex environments characterized by the delivery of a unique and differentiated care. In these units, errors always seem imminent and potentially harmful to patient safety. According to Fragata (2011, p. 15), "the possibility of occurrence of an incident or accident results from the complexity of the disease and/or associated treatment".

This study aimed to translate, adapt, and validate the Safety Attitudes Questionnaire - Intensive Care Unit version (SQA-ICU; Sexton et al., 2006) for the Portuguese population of nurses, with the purpose of contributing to the implementation of strategies for improving the quality of care and, consequently, increasing health gains. The target population of this study consisted of nurses working in intensive care units.

The SAQ-ICU (Sexton et al., 2006), which measures the safety climate in ICUs, was translated, adapted, and validated for the population of Portuguese nurses.

\section{Background}

The World Health Organization (WHO, 2009) argues that patient safety should be the cornerstone of health care and admits that the process of care delivery involves a certain degree of uncertainty.

In 2011, the Directorate-General for Health published a technical report detailing the structure of the International Classification for Patient Safety. This report mentions the WHO
2002 (World Healh Assembly - WHA; 55.18 resolution), which urges Member States "to pay the closest possible attention to the problem of patient safety and to establish and strengthen science-based systems necessary for improving patients' safety and the quality of health care" (Ministério da Saúde, Direção-Geral da Saúde, 2011, p. 4).

Pronovost and Rubenfeld (2009) gathered implementation strategies to improve the quality of care and, consequently, patient safety, namely bundles, protocols, checklists, audits and feedback, automatic functions, social marketing, and thought leadership.

Fernandes and Queirós (2011) concluded that only a small percentage of surveyed nurses believe that patient safety is a constant concern for the institution and that only $44 \%$ of them gave a positive perception of the hospital administration's support to patient safety.

In turn, Rodrigues and Ferreira $(2011$, p. 8), in a study with nurses ICUs in the north region of Portugal, showed that:

Stress can entail repercussions at individual, social and organizational level, which appear in terms of absenteeism, turnover rate, decreased worker performance, decreased motivation and work satisfaction, increased number of occupational accidents and increased performance errors.

In a study on nurses' attitudes towards errors, Coli, Anjos, and Pereira (2010) concluded that nurses often do not realize that they have made an error, and that sometimes they identify an error but do not report it. In addition, despite recognizing the importance of reporting errors, nurses decide not to report an error because they consider it to be irrelevant for the patient's condition or because they are uncertain of the repercussions in case they are identified as having caused the error. This means that, due to the culture of punishment in many institutions, only a small number of errors are reported.

There is a lot of work to be done in this area and there are still many barriers that need to be overcome.

\section{Methodology}

This methodological study had a quantitative, observational, and cross-sectional approach.

The sample was composed of 120 nurses work- 
ing in a total of six ICUs for adults (polyvalent, cardiology, and cardiothoracic surgery units) of three central hospitals (EPE) in the north region of Portugal.

The original data collection instrument - SAQICU - was designed by Sexton et al. (2006). It is composed of sociodemographic and professional questions, as well as questions that measure participants' perceptions of patient safety attitudes in ICUs. It also includes a question to describe the quality of the relationship with other members of the multidisciplinary team and a question about three important recommendations for improving patient safety at the unit. The questions are answered on a Likert-type scale and are divided into six dimensions: Teamwork climate, Safety climate, Job satisfaction, Stress recognition, Perceptions of management, and Working conditions.

The instrument was translated, adapted, and validated for the Portuguese population based on the recommendations and procedures put forward by Ribeiro (2010). No differences were found that could change the conceptual understanding.

In order to verify the effectiveness and value of the data collection tool, as well as to identify any imperfections (Fortin, 2009), a pilot study was conducted with a group of bilingual nurses who had good knowledge of Portuguese and English. These nurses worked in an ICU but were not included in the study sample. Based on the analysis of results and suggestions concerning the translation of the original instrument, only small changes were made to the syntax.

Data were analyzed using descriptive and inferential methods. The level of significance was set at $p<0.05$ and internal consistency was verified by calculating Cronbach's alpha coefficient, seeking values above 0.75 (Marôco, 2010). Pearson's correlation coefficient (Martinez \& Ferreira, 2010) was calculated. The Kaiser-Meyer-Olkin $(\mathrm{KMO}=0.865)$ test and Bartlett's test of sphericity $\left(X^{2}=2112.593 ; p \leq 0.005\right)$ were performed, which allowed conducting a factor analysis with Varimax rotation.

All ethical principles were complied with, namely requesting the authors' permission to use the SAQ-ICU, the authorization of the institutions' boards of directors to conduct the study, and the respondents' consent.

\section{Results}

Most of the study participants were women (65.8\%), aged 23 to 60 years (mean age of 37.59 years, standard deviation of 7.04). The most frequent age group was between 31 and 40 years $(55.9 \%)$, and the less frequent was over 50 years (4.9\%).

The original questionnaire was translated by an independent bilingual translator who was accredited by the Lancaster College and back-translated by an independent bilingual translator who was accredited by the Bristol School. The English and Portuguese versions were compared and no differences were found between them.

The Portuguese version of the SAQ-ICU was applied to a sample of 120 nurses who worked in ICUs.

The SAQ-ICU total score showed a high reliability, with an alpha value of 0.873 , which was higher than the one found in some studies listed by Sexton et al. (2006). An analysis of each dimension showed alpha values higher than 0.75 in four dimensions. However, the dimensions Teamwork climate and Working conditions showed alpha values of 0.623 and 0.631, respectively. Marôco (2010) emphasizes that, although an alpha exceeding 0.7 is desirable in most studies, values around 0.60 may be acceptable in social sciences studies. Thus, the Portuguese version of the SAQ-ICU (Questionário de Atitudes de Segurança - versão cuidados intensivos, QAS-UCI) has psychometric properties that validate the questionnaire (Table 1). 
Table 1

Cronbach's alpha coefficient according to the dimension and total score

\begin{tabular}{lcc}
\hline Dimensions & Cronbach's alpha & Number of items \\
\hline Teamwork climate & 0.623 & 8 \\
Safety climate & 0.847 & 8 \\
Job satisfaction & 0.754 & 5 \\
Stress recognition & 0.835 & 6 \\
Perceptions of management & 0.794 & 3 \\
Working conditions & 0.631 & 4 \\
QAS-UCI Total & 0.873 & 34 \\
\hline
\end{tabular}

Table 2 shows the values obtained in Pearson's correlations $(r)$ between the different dimensions, as well as the $p$-value demonstrating the correlation between different variables (Fortin, 2009). According to this author, $p$-values closer to 1.00 indicate a stronger correlation between two variables.

The analysis of the results showed that the dimension Safety climate is strongly correlated with the total QAS-UCI $(r=0.830, p=0.000)$, as well as with the dimensions Working conditions and Teamwork climate $(r=0.700, p=$ 0.000 , and $r=0.785, p=0.000$ respectively).
The dimension Working conditions had a good correlation with the total QAS-UCI and a reasonable correlation with the other dimensions $(r$ values between -0.250 and 0.700 ) with $p$-values $<0.05$.

Negative correlation values were found in the dimension Stress recognition (with the exception of the correlation with the total QAS), which was also observed in similar studies (Saraiva, 2015).

The remaining dimensions were strongly inter-correlated, with values close to the desirable $p$-values close to 1.00 .

Table 2

Pearson's correlation between dimensions and total score

\begin{tabular}{|c|c|c|c|c|c|c|c|c|}
\hline & & $\begin{array}{l}\text { Safety } \\
\text { Climate }\end{array}$ & $\begin{array}{l}\text { Working } \\
\text { Conditions }\end{array}$ & $\begin{array}{l}\text { Percep. } \\
\text { Manag. }\end{array}$ & $\begin{array}{l}\text { Stress } \\
\text { Recog. }\end{array}$ & $\begin{array}{c}\text { Job } \\
\text { Satisf. }\end{array}$ & $\begin{array}{l}\text { Teamw. } \\
\text { Climate }\end{array}$ & $\begin{array}{c}\text { Total } \\
\text { QAS-UCI }\end{array}$ \\
\hline \multirow{2}{*}{$\begin{array}{l}\text { Safety } \\
\text { Climate }\end{array}$} & $\begin{array}{c}\text { Pearson's } \\
\text { correlation }\end{array}$ & 1 & $0.700^{* *}$ & $0.453^{* *}$ & $-0.296^{* *}$ & $0.537^{* *}$ & $0.785^{* *}$ & $0.830^{* *}$ \\
\hline & $\begin{array}{c}\text { Sig. }(2 \\
\text { extremities) }\end{array}$ & & 0.000 & 0.000 & 0.001 & 0.000 & 0.000 & 0.000 \\
\hline \multirow{2}{*}{$\begin{array}{l}\text { Working } \\
\text { Conditions }\end{array}$} & $\begin{array}{c}\text { Pearson's } \\
\text { Correlation } \\
\end{array}$ & $0,700^{* *}$ & 1 & $0.477^{* *}$ & $-0.250^{* *}$ & $0.570^{* *}$ & $0.671^{* *}$ & $0.766^{* *}$ \\
\hline & $\begin{array}{c}\text { Sig. (2 } \\
\text { extremities) }\end{array}$ & 0,000 & & 0.000 & 0.006 & 0.000 & 0.000 & 0.000 \\
\hline \multirow{2}{*}{$\begin{array}{l}\text { Perceptions of } \\
\text { Management }\end{array}$} & $\begin{array}{c}\text { Pearson's } \\
\text { Correlation } \\
\end{array}$ & $0,453^{* *}$ & $0.477^{* *}$ & 1 & $-0.266^{* *}$ & $0.549^{* *}$ & $0.435^{* *}$ & $0.579^{* *}$ \\
\hline & $\begin{array}{c}\text { Sig. (2 } \\
\text { extremities) }\end{array}$ & 0,000 & 0.000 & & 0.003 & 0.000 & 0.000 & 0.000 \\
\hline \multirow{2}{*}{$\begin{array}{c}\text { Stress } \\
\text { Recognition }\end{array}$} & $\begin{array}{l}\text { Pearson's Cor- } \\
\text { relation } \\
\end{array}$ & $-0,296^{* *}$ & $-0.250^{* *}$ & $-0.266^{* *}$ & 1 & -0.124 & $-0.222^{*}$ & 0.055 \\
\hline & $\begin{array}{c}\text { Sig. }(2 \\
\text { extremities) }\end{array}$ & 0,001 & 0.006 & 0.003 & & 0.177 & 0.015 & 0.549 \\
\hline \multirow{2}{*}{$\begin{array}{c}\text { Job } \\
\text { Satisfaction }\end{array}$} & $\begin{array}{l}\text { Pearson's Cor- } \\
\text { relation } \\
\end{array}$ & $0,537^{* *}$ & $0.570^{* *}$ & $0.549^{* *}$ & -0.124 & 1 & $0.627^{* *}$ & $0.754^{* *}$ \\
\hline & $\begin{array}{c}\text { Sig. (2 } \\
\text { extremities) }\end{array}$ & 0,000 & 0.000 & 0.000 & 0.177 & & 0.000 & 0.000 \\
\hline
\end{tabular}




\begin{tabular}{ccccccccc}
\hline \multirow{2}{*}{$\begin{array}{c}\text { Teamwork } \\
\text { Climate }\end{array}$} & $\begin{array}{c}\text { Pearson's Cor- } \\
\text { relation }\end{array}$ & $0,785^{* *}$ & $0.671^{* *}$ & $0.435^{* *}$ & $-0.222^{*}$ & $0.627^{* *}$ & 1 & $0.869^{* *}$ \\
\cline { 2 - 8 } & $\begin{array}{c}\text { Sig. }(2 \\
\text { extremities })\end{array}$ & 0,000 & 0.000 & 0.000 & 0.015 & 0.000 & 0.000 \\
\hline $\begin{array}{c}\text { Tetal } \\
\text { QAS-UCI }\end{array}$ & $\begin{array}{c}\text { Pean's Cor- } \\
\text { relation }\end{array}$ & $0,830^{* *}$ & $0.766^{* *}$ & $0.579^{* *}$ & 0.055 & $0.754^{* *}$ & $0.869^{* *}$ & 1 \\
\hline $\begin{array}{c}\text { Sig. }(2 \\
\text { extremities })\end{array}$ & 0,000 & 0.000 & 0.000 & 0.549 & 0.000 & 0.000 \\
\hline
\end{tabular}

Based on the analysis of the mean scores in the different dimensions, it can be concluded that nurses have a positive perception of safety climate in most dimensions, with the exception of the dimension Perceptions of management, which had a lower score when compared to the benchmark.

Despite nurses' positive perception of the safety climate, this score remains below the desirable value that Sexton et al. (2006) consider as an indicator of a strong safety climate. There was a variation between the dimensions Perceptions of management and Safety climate, which showed mean scores of 33.4 and 67.5 , respectively.

The analysis of each dimension showed that the score found in the dimension Teamwork climate was slightly lower than the benchmark. Although it is recognized as an important factor in patient safety, none of the scores were close to the expected ones (mean score of 75).

As regards the dimension Safety climate, the mean score (67.5) was slightly higher than the benchmark (65.9). The organization can refer both to the boards of directors that issue general guidelines and to the heads of the service, who are responsible for promoting a high level of safety climate (Fragata, 2006).

Job satisfaction refers to professionals' perception of their work and their motivation to perform their functions. In addition to financial compensation from their work, emotional aspects and personal and professional accomplishment are equally important factors for a high level of job satisfaction (Rodrigues, 2011). The analysis of the results obtained in this dimension showed a mean score of 58.0. Although it is above
50, this score remains slightly below the benchmark.

In the dimension Stress recognition, the obtained mean score of 63.5 is slightly below the benchmark (67.8). Although the score suggests that professionals have a positive perception of this dimension, it is still far from being a predominantly positive perception. Reducing stress can contribute to reduce its potential impact on professionals' health and well-being (Rodrigues \& Ferreira, 2011).

As already mentioned, the lowest mean score (33.4) was found in the dimension Perceptions of management, which is lower than the score considered as an indicator of highly positive perception of management (75.0) and slightly below the benchmark (46.4). This score reflects a possible distancing between health care professionals and the managers of the institution where they work (Saraiva, 2015).

The mean score found in the dimension Working conditions (54.5) is very close to the reference score found by the authors (Sexton et al., 2006). Working conditions include aspects related to the physical structure of the service/organization, as well as the available human and material resources and the access to continuous training. Professionals consider that these are relevant aspects that require further development.

In the question regarding the quality of the collaboration with members of other professional categories, the results varied according to the professional category. In this dimension, the quality of the relationship between nurses, specialist nurses, and operational assistants is high or very high (Table 3). 
Table 3

\begin{tabular}{|c|c|c|}
\hline Dimensions & (QAS-UCI) & $\begin{array}{c}\text { Benchmark } \\
\text { (Sexton et al., 2006) }\end{array}$ \\
\hline Teamwork climate & 61.4 & 68.5 \\
\hline Safety climate & 67.5 & 65.9 \\
\hline Job satisfaction & 58.0 & 63.6 \\
\hline Stress recognition & 63.5 & 67.8 \\
\hline Perceptions of management & 33.4 & 46.4 \\
\hline Working conditions & 54.5 & 55.9 \\
\hline
\end{tabular}

With regard to the recommendations for improving inpatients' safety in the units where they work, 36 of the sampled nurses (30\%) provided a total of 82 recommendations on two safety culture aspects: human factors $(31.7 \%)$ and organizational factors (68.3\%). Communication was the most commonly reported human factor, while training, work schedule, staffing, workload, practices and procedures, and physical conditions were some of the most common recommendations related to organizational factors.

\section{Discussion}

All statistical procedures performed in the QAS-UCI to analyze its reliability and validity, as well as the results obtained, confirmed that this data collection tool is reliable and capable of measuring nurses' perceptions of patient safety attitudes in the Portuguese context.

The process of translation and cultural adaptation of the SAQ-ICU into Portuguese followed the scientific requirements put forward by multiple relevant authors in the scientific community. The rigorous scientific procedures resulted in a questionnaire that can be applied to the Portuguese population.

With regard to the different dimensions of the questionnaire, the analysis show that the sampled nurses have slightly less positive perceptions than the benchmark in the dimension Teamwork climate. Teamwork is a key factor for the correct functioning of organizations. Teams are able to minimize their weak- nesses, provide multiple perspectives on the same issue, and improve their performance since they can develop more and better work than a single individual (Maxwell, 2008). The same author cites the former North-American President Woodrow Wilson to say that "We should not only use all the brains we have, but all that we can borrow" (Maxwell, 2008. p. 22).

The mean score found in the dimension Safety climate was higher than the benchmark, which shows that organizations have a positive attitude towards this dimension.

Job satisfaction is also an indicator of the quality of care delivery; thus, organizations should strive to improve the available structural conditions and resources in professional environments (Rodrigues \& Ferreira, 2011). The mean score obtained in the dimension Stress recognition was slightly below the benchmark. In ICUs, stress can be a constant or imminent presence as a result of the unit's characteristics. Reducing stress can contribute to reduce its potential impact on the health and well-being of both professionals and individuals who depend on these professionals in case of a disease (Rodrigues \& Ferreira, 2011).

As mentioned above, the lowest mean score was found in the dimension Perceptions of management, which was significantly below the score associated with a highly positive perception of management. This score reflects a possible distancing between health care professionals and the managers of the institution where they work. The expenditure cuts resulting from the socioeconomic situation 
in Portugal may be among the factors that promote this atmosphere. This situation has a direct impact on the professionals' daily practice and may demotivate them and push them away from the decision-making bodies (Saraiva, 2015).

The mean score found in the dimension Working conditions is very close to the reference score found by the authors of the original questionnaire (Sexton et al., 2006). Working conditions include aspects related to the physical structure of the service/organization, as well as the available human and material resources and the access to continuous training. Professionals consider that these are relevant aspects that require further development.

The respondents made several recommendations on various patient safety culture aspects related to human and organizational factors.

Among human factors, nurses mentioned communication more often, which demonstrates their concern with this key aspect of patient safety. Communication between the members of the multidisciplinary team emerges as one of the main aspects to be improved in the ICU. Several authors emphasize the importance of this aspect, namely the WHO (2008), which considers communication as essential to patient safety, and Santos, Grilo, Andrade, Guimarães, and Gomes (2010), who recognize the importance of an effective communication between health professionals.

The recommendations related to organizational factors are more diversified than human factors and include training, work schedule, staffing, workload, practices and procedures, physical conditions. These results are in line with those obtained by Rooney, Heuvel, and Lorenzo (2002), in their description of the organizational factors that are involved in care delivery and patient safety. Nurses are concerned with factors such as the reduction of working hours, the increase of the number of professionals to reduce the workload, the improvement of in-service training for all professionals, and the promotion of a constructive safety culture with an effective error reporting system, having mentioned them in the last question of the data collection instrument. Nurses are not directly responsible for these factors but have identified them as having a direct impact on their daily practice and, consequently, on patient care.

This study provides an important contribution to understanding the issue of patient safety, and the validation of this questionnaire will promote the development of further research in this area to enhance the existing knowledge about the safety culture in complex environments such as ICUs.

\section{Conclusion}

Patient safety has been an increasingly relevant focus of attention in all societies. The development of interventions aimed at improving health care quality and, consequently, patient safety is becoming a necessity. However, there are still some barriers to the implementation of these measures. These barriers often relate to economic factors.

Nurses recognize the need to improve specific areas, namely the number of professionals providing care to patients, the disruption of care continuity, the professionals' workload, and clinical error management. In addition, there is still work to be done if organizations are to achieve increasingly high levels of quality in care delivery.

High levels of patient safety are only possible if the existing problems are appropriately reported and openly discussed, rather than ignored. It is essential to recognize the existing problems and their magnitude to better prepare the future. Appropriate strategies must be developed with the purpose of creating more efficient health systems, even if national policies are a constraining factor in organizations.

Therefore, nurses should continue to reflect on existing issues and assume their important role in organizations and the society in general, by developing research studies that will improve the knowledge about the current realities.

This study found that the Portuguese version of the SAQ-ICU has good psychometric properties, thus making it a valid and reliable tool for the Portuguese population. 


\section{References}

Coli, R. C., Anjos, M. F., \& Pereira, L. L. (2010). Postura dos enfermeiros de uma unidade de terapia intensiva frente ao erro: Uma abordagem à luz dos referenciais bioéticos. Revista Latino-Americana de Enfermagem, 18(3), 27-33.

Fernandes, A., \& Queirós, P. (2011). Cultura de segurança do doente percecionada por enfermeiros em hospitais distritais portugueses. Revista de Enfermagem Referência, 3(4), 37-48.

Fragata, J. (2006). Risco clínico: Complexidade e performance. Coimbra, Portugal: Almedina.

Fragata, J. (2011). Segurança dos doentes: Uma abordagem prática. Lisboa, Portugal: Lidel.

Fortin, M. F. (2009). Fundamentos e etapas do processo de investigação. Loures, Portugal: Lusodidacta.

Marôco, J. (2010) Análise estatística com o PASW Statistics (ex SPSS). Sintra, Portugal: ReportNumber.

Martinez, L. F., \& Ferreira, A. I. (2010). Análise de dados com SPSS: Primeiros passos ( $3^{\mathrm{a}}$ ed.). Lisboa, Portugal: Escolar Editora.

Maxwell, J. C. (2008). As 17 incontestáveis leis do trabalho em equipe. Rio de Janeiro, Brasil: Thomas Nelson.

Ministério da Saúde, Direção-Geral da Saúde. (2011). Estrutura conceptual da classificação internacional sobre a segurança do doente. Lisboa, Portugal: Autor.

Pronovost, A., \& Rubenfeld, G. (2009). Quality in critical care. In J. D. Chiche, R. Moreno, C Putensen, \& A. Rhodes (Eds.), Patient safety and quality of care in intensive care medicine (pp. 127-137). Berlin, Deutschland: Mwv Medizinisch Wissenschaftliche Verlagsgesellschaft Ohg.

Ribeiro, J. L. (2010). Metodologia de investigação em psicologia e saúde ( $\left.3^{\mathrm{a}} \mathrm{ed}\right)$. Porto, Portugal: Legis Edi-
tora/Livpsic.

Rodrigues, I. G. (2011). Satisfação profissional dos enfermeiros de uma unidade de cuidados intensivos (Master's dissertation). Retrieved from http://hdl. handle.net/10400.14/10893

Rodrigues, V., \& Ferreira, A. (2011). Fatores geradores de estresse em enfermeiros de Unidades de Terapia Intensiva. Revista Latino-Americana de Enfermagem, 19(4), 1-9.

Rooney, J. J., Heuvel, L. N., \& Lorenzo, D.K. (2002). Reduce human error. How to analyze near misses and sentinel events, determine root causes and implement corrective actions. American Society for Quality, 9, 27-36.

Santos, M. C., Grilo, A., Andrade, G., Guimarães, T., \& Gomes, A. (2010). Comunicação em saúde e a segurança do doente: Problemas e desafios. Revista Portuguesa de Saúde Pública, 10, 47-57.

Saraiva, D. F. (2015). Tradução, adaptação cultural e validação do Safety Attitudes Questionnaire: Short Form 2006 para Portugal (Master's dissertation). Retrieved from http://ubibliorum.ubi.pt/handle/10400.6/3429.

Sexton, J. B., Helmreich, R. L., Neilands, T. B., Rowan, K., Vella, K, Boyden, J., ... Thomas, E. J. (2006). The Safety Attitudes Questionnaire: Psychometric properties, benchmarking data, and emerging research. BioMed Central Health Services Research, 6(44), 1-10. Retrieved from http://www.biomedcentral.com/1472-6963/6/44

World Health Organization. (2008). Learning from error. Geneva, Switzerland: Author.

World Health Organization. (2009). Humans factors in patient safety: Review of topics and tools. Geneva, Switzerland, Author. 